Evangelikal: Jurnal Teologi Injili dan Pembinaan Warga Jemaat

ISSN 2548-7868 (print), 2548-7558 (online)

Availabel at https://journal.sttsimpson.ac.id/index.php/EJTI/

DOI: https://doi.org/10.46445/ejti.v6i1.425

\title{
Christian Ethics Regarding Cryptocurrency Investment
}

\author{
Styadi Senjaya, ${ }^{1 *}$ Ferry Simanjuntak $^{2}$ \\ ${ }^{1,2}$ Sekolah Tinggi Teologi Kharisma Bandung, Indonesia \\ *email: styadisenjaya0705@gmail.com
}

\begin{abstract}
Cryptocurrency is a digital currency that utilizes blockchain technology to do investments. This study aims to provide answers for Christians on how to respond to Cryptocurrency investments from the perspective of Christian ethics. The research method used is through the library research approach. This study indicates that cryptocurrency itself as a new technology is an agnostic technology; rather, it is the attitude and motivation of a person that determines the suitability of cryptocurrency in a particular situation. Thus, pastors and believers can invest in cryptocurrency, depending on their motivations.
\end{abstract}

Key Words: Investment, Bible Perspective, Cryptocurrency, Technology

Article History:

Submitted: July 06, 2021

Revised: Nov. 15, 2021

Published: Jan. 28, 2022

This is an open access article under the CC BY-SA license (c) (i) (2)

\section{INTRODUCTION}

In this era of technological advancement, the impact is not only felt on access to unlimited information (i.e., such as through the internet). There is also an effect in the investment sector. Investments that were previously limited to several means such as currency, gold, and mutual funds, Peer Lending, stocks, bonds and so on are now growing. With these perceived technological developments, people's lives are more effective and efficient (Nurjannah \& Artha, 2019). Investments that previously could only be done offline, can now be shortened by the implementation of technology that is renewable with time and systems.

Types of investment instrument underwent a very significant change, especially when the blockchain system was introduced and adapted to a financial system that is currently developing, namely cryptocurrency (Yulianton et al., 2018). This blockchain system supports pruning on trust parties or trusted third parties such as banks. By pruning this system, it makes this system run faster and more transparently (Misra et al., 2020). This cryptocurrency has the same function as other currencies, but what distinguishes it is that this cryptocurrency does not have a physical form, but only a block of data and has a hash as validation (Razzaq, 2018).

With the emergence of cryptocurrencies, there are pros and cons as to its use in various countries, due to legal issues and also regulations on users. In Indonesia itself, this study is still being carried out regarding the Badan Pengawas Perdagangan Berjangka Komoditi (Bappeti) for cryptocurrency assets (Meima \& Pratama, 2018).

In this study, we will discuss how to view cryptocurrency investment instruments from a Christian ethical perspective. In contrast to published research that examines cryptocurrencies regarding the use of cryptocurrencies as a means of payment, the result is that cryptocurrency cannot be used as legal tender in Indonesia because the Constitution only legitimizes the use of rupiah (Nurjannah \& Artha, 2019). Other researchers who examine the price-forming factors of cryptocurrencies are seen from the determinants of traditional market prices, 
market forces in supply and demand, as well as specific factors of cryptocurrencies (Dwyer, 2015). Further research on cryptocurrency prices can be predicted with two important factors: namely, momentum and the interest of investors themselves (Liu \& Tsyvinski, 2021). Meanwhile, in other studies from the legal field regarding the legality of cryptocurrencies in Indonesia itself, it can only be regulated through the Ministry of Trade because cryptocurrency is a crypto asset that is the subject of the future cotracts that can be traded on futures exchanges (Puspasari, 2020). Other researchers from the Information Technology side are researching the use of blockchain technology that can be used with support from various sides such as regulation and the economy (Yulianton et al., 2018). Ecological researchers examine the impact of cryptocurrency mining on the environment which will be seen in the very long term and have a wide ranging impact on human life (Vranken, 2017).

The current research aims to construct a Christian ethic toward Cryptocurrency, so that the results will provide direction to Christians in dealing with cryptocurrency investment wisely and in accordance with Bible truth. There is still little research on Christian ethics in investing in cryptocurrency instruments; thus, this research was conducted to assist pastors and ministers in providing correct understanding to the congregations they serve. Following, this study will examine how Christian ethics are regarding cryptocurrency investment.

\section{METHOD}

In this study, the researchers looked at the opinions of several experts both in theology and economics who discussed investing in cryptocurrency, both in journal articles and books. Because this research is from the perspective of Christian ethics, we look at Scripture shape their view on cryptocurrency investments. Then we observe the security of technology, transaction costs, high profits, legality, maintenance costs, market crashes, and the bubble effect, viewed from a biblical point of view. Only after that can we draw conclusions concerning a Christian response to cryptocurrency. The results and discussion in this study will be described using a descriptive method, so that it can be explained clearly and precisely.

\section{RESULTS AND DISCUSSION}

To determine Christian ethics regarding investing in cryptocurrency instruments, it is necessary to examine more deeply the reasons put forward for cryptocurrency. Behind the pros and cons that come out from various circles, this needs to be carefully examined. Cryptocurrency itself is believed to have several special benefits compared with banks and physical forms of payment (e.g., credit cards and cash).

\section{Technology Security}

Because of the use of blockchain in cryptocurrencies, of course, there is efficiency in the transaction system carried out. Blockchain is a technology used as a digital data storage system that is connected via cryptography. Then, in a study it was proven that with the use of a blockchain system, blockchains were able to protect the information held by users and also reduce the involvement of third parties (Ying et al., 2018).

However, this fact does not make cryptocurrencies immune from risk. One of the many risks that can occur is the occurrence of multiple transactions, which means there can be two transactions on one coin at the same time (Tschorsch \& Scheuermann, 2016). The high level of security offered by this blockchain system can also be directed if hackers can control the hash as a validation method used in this system.

However, this also cannot deny that the system implemented in cryptocurrency is more secure than the system used on credit cards. Whatsmore, the processing costs given are also lower (Alstyne, 2014). So, when compared to the process carried out by cryptocurrencies with credit, 
it is shorter and more efficient because it has an authentic address that is owned by both the buyer and the seller.

Seeing the part of security that is applied to cryptocurrencies through blockchain, it is necessary to see how the Bible views existing technological advances (Dwyer, 2015). The Bible basically does not reject technological progress, because it is God himself who gives gifts and also the ability for humans to develop everything, one of which is technology. For example Exodus 35:30-31 relates how God equipped Bezalel son of Uri son of Hu of the tribe of Judah with skill, understanding, and knowledge (Tampubolon et al., 2010). The word

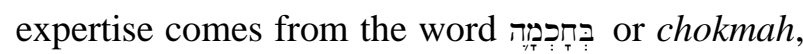
which is also used to express someone who is skilled or full of abilities. While the words that come from the word וּבְתבוּנה or tebunah used to describe expertise (Wagner, 2005).

Therefore, a person's expertise to develop his talent by producing something new also comes from God, as well as the invention of blockchain technology. However, people need to respond and use blockchain technology wisely to simplify human life and even glorify God's name.

\section{Transaction Fee}

From ancient times, humans have known transactions carried out by exchange. In the past, humans used a barter system (goods for goods). However, to get the value of the item comes to the currency. In an advanced civilization like this, cryptocurrencies provide a major breakthrough in human life, especially in transactions.

The use of cryptocurrency as a transaction tool has a lower cost than other transaction tools (Kim, 2017). The use of conventional transactions used in banks has a higher cost. Credit or debit cards have certain fees, such as administration, transfer fees of varying amounts. However, this is different from cryptocurrencies which, although they have costs, have a smaller amount (Angel \& McCabe, 2015).
In terms of operational hours, cryptocurrency has another advantage, becauses cryptocurrency operates 24 hours non-stop every day. This is different from conventional banks which operate for 5 working days and are closed on holiday. So, users can make transactions at any time, without being limited by operating hours. As long as there is an internet-connection, users can make local and even foreign transactions (Pieters \& Vivanco, 2017).

With the use of cryptocurrencies like this, it will be easier to be accepted by the younger generation who want effectiveness in all things. So, with this fact, it is possible that cryptocurrencies like this can be used in business. Cryptocurrencies provide convenience in transactions, cheaper fees, and are not limited by time.

When viewed from a biblical point of view, even Jesus in the Bible still insists on the people to continue to pay taxes to Caesar as an obligation that must be done by the Israelites (Matthew 22:15-22). At that time many people whose taxes were imposed by the Romans such as land taxes, personal taxes (Luke 2:1-5), and customs duties. Because the tax rules that Rome imposed on Israel were the main cause of the poverty felt by the Israelis at that time (Hendricks, 2006). In addition, Israel also had to pay taxes to Rome and taxes to Herod, who was an arm of the Roman rulers at the time. As a result, the people couldn't have leftover agricultural produce for the families (Baron, 1952). The point is, with a system that is transparent and reduces the existing transaction costs, believers should not use it to avoid their obligations, such as reporting and paying taxes.

This also needs to be done by Christians as a means of being an example for those around them, even for employees who work in a business. Submission to the government by carrying out obligations is one of the means for the people to become an example, because, first of all, they are imitating Jesus. The Bible says that honesty both in word and deed is a major aspect of God's character 
and therefore should characterize His people as well in everything they do, one of which is the payment of obligations such as taxes. Cases of dishonest transactions are also prohibited in Jewish law (Deuteronomy 25:13-16; Proverbs 11:1; Ezekiel 45:9-12)/(Beaumont, 2018). Therefore, the Bible always commands us to state the truth (Matthew 23:16-28; Ephesians 4:25-32).

\section{High Profit}

Perhaps the biggest claimed advantage of using cryptocurrency is making a large profit. This is due to the highly volatile movement of cryptocurrency so that it can provide very large profits; on the other hand it can also at the same time provide very large losses. As many investors know, in making investments, the theory is to buy at a low price and sell at a high price (Brière et al., 2015).

At the beginning of the emergence of Bitcoin, it was noted that this cryptocurrency made history by providing profits of $1,000-10,000 \%$ for investors whose money was in this cryptocurrency. (Becker et al., 2013). Of course, recording this history makes other users interested in investing in this cryptocurrency. In addition, the popularity of this cryptocurrency is also in demand by various people who have influence to enter into cryptocurrency investment.

The reason the price of Bitcoin at that time could soar so high was a common reason in the trading world. Bitcoin has a quota on the number of coins it has. So, when bitcoin experiences scarcity, the price will also soar. However, when bitcoin hits a certain price, the user will sell the coin to get the profit he wants to get (Ciaian et al., 2016). However, the rise and fall of these cryptocurrencies are often influenced by the opinions of those in power. When such a person expresses a positive opinion about this cryptocurrency, the price will increase, and vice versa.

Despite the several advantages possessed by cryptocurrencies, cryptocurrency is also faced with various challenges that need to be taken into consideration. The Bible states gives many practical suggestions regarding gains in money. Money, if handled properly, can be a source of great blessing; but when money is handled unwisely, it can become a snare (Baker, 2019). However, the main problem that arises is not because of money, but the love of money (Timothy 6:10).

Jesus also in the Bible teaches a lot about money. His teaching is in line with Jewish tradition, namely, to not be concerned about wealth (Geisler, 2015). However, the concern that Jesus gave was how the wealth was used and what one could do for others with the wealth one had. Jesus wanted his followers to be generous to the poor (Matthew 6:24). Jesus also reminded people how wealth could be a barrier to entry into the kingdom of God (Luke 18:18-30). Therefore, what God's people do when they get big profits from cryptocurrencies needs to be remembered, whether it's just personal wealth or to become a channel of blessing for those around them (Mastra, 2019), so that the name of the Lord Jesus may be glorified.

\section{Legality}

Until now, it has been stated that $5 \%$ of internet users in Indonesia who have a form of cryptocurrency (Razzaq, 2018). With this fact, Indonesia is the country with the 5th largest number of cryptocurrency users in the world. Thus, with a large number of users of this cryptocurrency, the government continues to regulate, record market exchanges, and coins circulating in Indonesia to ensure that security that exists for users. Bappeti noted that there are already 13 market exchanges that are legally registered to be able to market this cryptocurrency commodity.

\begin{tabular}{ll}
\hline \multicolumn{1}{c}{$\begin{array}{c}\text { Market } \\
\text { Exchange }\end{array}$} & \multicolumn{1}{c}{ Company } \\
\hline Indodax & $\begin{array}{l}\text { PT. Indodax Nasional } \\
\text { Indonesia }\end{array}$ \\
\hline Tokocrypto & PT. Crypto Indonesia Berkat \\
\hline
\end{tabular}




\begin{tabular}{ll}
\hline Upbit & $\begin{array}{l}\text { PT. Upbit Exchange } \\
\text { Indonesia }\end{array}$ \\
\hline Triv & PT. Tiga Inti Utama \\
\hline Pintu & PT. Pintu Kemana Saja \\
\hline Zipmex & $\begin{array}{l}\text { PT. Zipmex Exchange } \\
\text { Indonesia }\end{array}$ \\
\hline Bicipin & PT. Bursa Kripto Prima \\
\hline Luno & PT. Luna Indoensia Ltd \\
\hline Rekeningku & PT. Rekeningku Dotcom \\
\hline Indonesia & PT. Indonesia Digital \\
Digital & Exchange \\
Exchange & PT. Cipta Koin Digital \\
\hline Koinku & PT. Triniti Investama Berkat \\
\hline Bitocto & PT. Plutonext Digital Aset \\
\hline Plutonext
\end{tabular}

Table 1. Market Exchange in Indonesia 2021

Meanwhile, as of today, there are 229 types of cryptocurrencies registered with Bappebti (Peraturan Bappebti Nomor 7 Tahun 2020, 2020).

With so many cryptocurrencies scattered in commodity trading in Indonesia, the legality of the laws that regulate them is still lacking, so it is necessary to be careful in conducting transactions with cryptocurrency. However, with the lack of existing legality, this is supported by the many countries that do not approve of trading this cryptocurrency, for example, China (Cheung et al., 2015). China has become a major country that prohibits and prohibits the use of cryptocurrency in institutions and businesses. The biggest reason put forward is that it is difficult to monitor transactions that occur with cryptocurrencies because every user who makes transactions is anonymous.

Romans 13:1 gives a warning to everyone to submit to their respective governments. The word

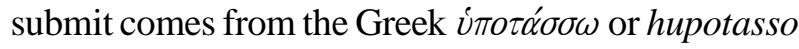
which means subject to applicable law. So, currently it continues to run contrary to the applicable law or does not even have a legal basis, is this true. The government that exists today is God's representative in the world. What comes out in the form of applicable law is one of the things that every society needs to obey. Obedience to government describes obedience to human beings (Mastra, 2019).

Until now, cryptocurrency is only recognized as an item and not a currency. So, the treatment of its use must remain up to the limit of the goods used, and not as a medium of exchange like a currency. If this can be held to by cryptocurrencies users, then this can be a picture of the principles that the people have for the government.

\section{Huge Maintenance Cost}

To be able to mine cryptocurrencies, besides needing to buy quite expensive devices, users also need to pay more to pay for electricity. This is because the cryptocurrency mining process requires a large amount of electrical energy. Mining can take up to 10 megawatts until 3-6 gigawatts, based on the results of research conducted in Bangladesh and also Denmark (Vranken, 2017). Because the use of electricity is quite large, this also causes very large emissions. Thus, the process carried out in mining is not environmentally friendly.

The movement towards concern for environmental sustainability is not a new thing. Many individuals have communicated the importance of caring for the environment such as Henry David Thoreau (1817-1862), John James Audubon (1851), John Muir (1914), John Burroughs (1921), Theodore Roosevelt (1919), and Gifford Pinchot (1946) (Geisler, 2015). The Bible describes the universe and the environment as a reflection of God's glory as of the Creator (Psalms 19:1; 1 Timothy 4:4). God is the Creator and thus also the owner of the earth, and has entrusted it to humans to care for. In the message that God gave to humans at the beginning of creation he commanded humans to be rule and subdue (Genesis 2:15). So So humans are given power over living things. To conquer (kabas) means to guard or maintain (Kusnandar, 2017). This word implies how the form of human control or power over nature (Geisler, 2015). Then 
the word power (rada) which means win over. Gives a picture of someone who is dominant or who wins. If the description between these two words will be combined by asserting that humans are not only in the night but also placed above nature (Keraf, 1995).

In addition, human existence is also an obligation to be able to maintain. Verb ( $a b a d$ ) means to serve (Genesis 2:15)/(Setiawan, 2021). Another word for maintaining (samar) means to guard, supervise, or maintain. These two words describe how actions must be taken by humans for the sake of creation and not only human interests (Mastra, 2019). Humans are given the obligation to serve and care for the earth. Therefore, the use of cryptocurrencies needs to be taken into account in light of human responsibility to care for the earth. Thus, the actions taken by humans should not make the world's condition worse because of selfishness.

\section{Market Crash and Bubble Effect}

Investing in cryptocurrencies will be difficult, because one of the things that cryptocurrencies lack is information on the past that is useful for predicting the future (Urquhart, 2016). If cryptocurrencies have a strong enough history of past performance, then highly volatile movements in the cryptocurrency market will not occur. Every investor will make careful technical predictions before putting their money into this investment instrument (Fry \& Cheah, 2016). The volatile movement of this cryptocurrency is even higher than the movement of gold. According to one graph of the monthly moving average of gold and Bitcoin, gold is higher than the lowest point of the movement of Bitcoin (Dwyer, 2015). So from the results of this comparison, it is a very big risk to put money in cryptocurrency investments in the long term. This is because the risk of market collapse and the bubble effect is very large. It is recorded that from 2011 to 2013 there were three large bubble effects. The bubble effect is a phenomenon that occurs in crypto assets, where the price experiences a higher spike over time.

Seeing this highly volatile coin currency movement shows that the value can be driven by speculation in the absence of reliable fundamentals. This high volatile system can make the cryptocurrency no longer a viable currency, Then, the resulting bubble effect also makes the price of the cryptocurrency, which, when compared today with a few months later, can be far adrift (Blau, 2018). With such a high risk, investors must be wary so they don't do such an investment without any knowledge.

\section{Christian Ethics Regarding Cryptocurrency Investment}

The Bible several times records the attitude of people in managing the property that God has entrusted to the life of each individual. However, especially in investing in cryptocurrency instruments, there are things that every believer needs to pay attention to. The Bible gives many warnings about the attitude of the believer's heart regarding possessions or money. 1 Timothy 6:10 says that love of money is the root of all kinds of evil. When humans live only to make money, a life that deviates from faith is formed. A life that is always chasing money will never be satisfied. Ecclesiastes 5:10 clearly says that life's pursuit of money is futile, because money is impermanent. However, the Bible advises believers to be able to live contentedly with what God has given believers (Hebrews 13:5).

This does not mean that every warning in the Bible makes unbelievers manage their finances well. The principle that every believer needs to hold is "God is the owner and man is only the manager." Believers who today have assets or money need to be able to manage them as a form of responsibility to God. Proverbs 13:11 relates how God looks at faithfulness, not in the amount of savings or investments accumulated. Because whatever is owned by people, is on loan from God. God reminds 
us how believers need to be faithful in small things and as a result $\mathrm{He}$ will entrust with more important things. It is the same with the management of God's blessings. The amount that God gives to people is given in order to be managed well (Tampubolon et al., 2010).

In the Bible, there is a parable that Jesus used to illustrate the principle of "reward and punishment." Of course this principle provides an illustration of how to develop what has been entrusted to him and finally returned to God; not only what God has given, but also given along with the excess of interest (Tomatala, 2012). So, it is a natural thing for someone to want to develop what he has, in terms of money or even abilities. However, what ultimately matters is the return whether more is returned to God to glorify Him or if what was entrusted is hoarded for one's own interests, like the lazy servant of Luke 16:1-9. The Bible also shows the proper attitude of the heart that each believer should have. Proverbs 3:9-10 describes how believers can glorify God through the treasures that God has given to believers. Proverbs 28:20 also relates how the Bible says that for those who want to get rich quickly, they will not escape punishment; but those who are trusted will actually get a blessing (Tomatala, 2010). Colossians 3:17 describes how everything needs to be done with thanksgiving.

So, concerning the ethics of Christians in investing in cryptocurrency, we need to consider one's motivations. Is it greed and the desire to be rich a person's motivation or does the person know what God's purpose for investing is? God teaches believers to be a blessing to others. Is this the basis for believers in using cryptocurrency? The difference between wanting to accumulate assets to be a blessing to others and accumulating assets for oneself is a key one.

If you look more closely at Proverbs 3:9, the Hebrew word for your treasure means מִהוֹנֶ. This is said to be an expression for the Israelites to be able to believe in God's inclusion in the life of this nation. The Israelites at that time did not fully believe in God's inclusion and care in their lives. Word "mehoneka" It also means that the life of a believer can be lived easily. Because there is hope that is placed in God.

If we examine what Jesus believed in the Lord's Prayer (Matthew 6:11), Jesus taught his followers to pray, "Give us this day our daily bread." This is not just an empty prayer. It was an acknowledgment of the reality of life for most people in Jesus' day who had to be independent, living from cultivating the land. For farmers, the situation and natural conditions were everything (and still are!), and something beyond the control of the farmers themselves. So, farmers must fully surrender to God so that they will be given the best natural conditions throughout the year to produce good harvests (Keraf, 1995). This is what God's people need to learn today, that the right attitude of the heart is to completely depend on God and not depend on Cryptocurrencies.

In addition, the background of the Israelites as farmers also illustrates how the life of the people should be. Many aspects of Jewish law governed agricultural life (Lawrence, 2016). First, the care to be shown for animals at work or in the fields (Deuteronomy 22:10) or those in need (Deuteronomy 22:1-4). The Israelites could not live for their own sake: creation and one's fellow neighbor must be concerns as well. Second, owners are responsible for the actions of their animals (Exodus 21:28-36). Israelites were held accountable if their livestock make noise or even have a negative impact. Third, a farmer who inadvertently starts a fire is responsible if the fire spreads and destroys neighboring crops (Exodus 22:6). God's people are responsible for another. Likewise, if one wants to mine cryptocurrency, the environmental impact caused by it must be borne as well. Fourth, at harvest time, the crops were to be left on the edge of the field for the poor (Deuteronomy 24:19-22). The results obtained should not only be enjoyed by oneself, but must always be shared with those in 
need. Fifth, every seventh year (the Sabbath year), the land was to be left vacant (Leviticus 25:1-7, 1822) and every crop that grew was to be left for the poor and the animals (Exodus 23:10-11)/(Ronda, 2011).

The preceding discussion teaches us how the existence of human life cannot only be prioritized for itself. There must be a priority for others through what unbelievers get. The impact must also be felt by the people around (Bambangan, 2013). This is because the Bible also always describes God as the good Shepherd, who cares for His sheep (Genesis 48:15; Psalm 23; Isaiah 40:11; Ezekiel 34:7-31). We also see this illustration used by Jesus for Himself (John 10:1-16), Jesus realized from His statement, Jesus was not only revealing, but fulfilling it. The Gospels state that Jesus laid down His life as the True Shepherd to save His sheep (John 10:11, 17-18); this was a model and position that the early church needed to teach and defend (Hebrew 13:20; 1Peter 5:4)/(Ronda, 2011).

It is also not just focusing on one's self by ignoring moral and environmental responsibilities. However, it is necessary to imitate Jesus who has set the perfect example of a Good Shepherd.

\section{REFERENCES}

Alstyne, M. Van. (2014). Why Bitcoin has value. Communications of the ACM, 57(5), 30-32. https://doi.org/10.1145/2594288

Angel, J. J., \& McCabe, D. (2015). The Ethics of Payments: Paper, Plastic, or Bitcoin? Journal of Business Ethics, 132(3), 603-611. https://doi.org/10.1007/s10551-014-2354-x

Baker, D. L. (2019). Kekayaan dan Kemiskinan Menelusuri Keadilan Sosial menurut Hukum Perjanjian Lama. Yayasan Komunikasi Bina Kasih.

Bambangan, M. D. (2013). Mengelola Harta Kekayaan. ANDI.

Peraturan Bappebti Nomor 7 Tahun 2020, (2020). Baron, S. W. (1952). A Social and Religious History

\section{CONCLUSION}

Seeing that investment in cryptocurrency instruments is currently developing, there are still two growing opinions regarding the perspective of investing in cryptocurrency instruments themselves: pro-cryptocurrency, because this system promotes transparent transactions, thereby eliminating third parties who are usually the place where violations occur (e.g., money laundering, bribery, illegal transactions, etc); as well as a faster transaction process unfortunately, believers can invest in cryptocurrency with wrong motivations such as the desire to get rich quickly. However, with the motivation to be able to manage finances well, the results can be used to serve people in need. Belivers live not to make themselves rich but are to become a channel of blessing for others.

It is the authors' hope that this research has served to help pastors and churches to determine attitudes regarding the investment phenomenon that is currently happening in Indonesia in particular. This was merely the beginning of a way forward for viewing Christian involvement with cryptocurrency. May we continue to seek God's guidance in each of our congregations and make wise financial decisions with God's resources.

of the Jews. Columbia University Press.

Beaumont, M. (2018). Ensiklopedi Alkitab Tematik. Yayasan Komunikasi Bina Kasih.

Becker, J., Breuker, D., Heide, T., Holler, J., Rauer, H. P., \& Böhme, R. (2013). Can we afford integrity by proof-of-work? scenarios inspired by the bitcoin currency. In The Economics of Information Security and Privacy. https://doi.org/10.1007/978-3-642-39498-0_7

Blau, B. M. (2018). Price dynamics and speculative trading in Bitcoin. Research in International Business and Finance, 43, 15-21. https://doi.org/10.1016/j.ribaf.2017.07.183

Brière, M., Oosterlinck, K., \& Szafarz, A. (2015). Virtual currency, tangible return: Portfolio 
diversification with bitcoin. Journal of Asset Management, 16(6), 365-373. https://doi.org/10.1057/jam.2015.5

Cheung, A. W.-K., Roca, E., \& Su, J.-J. (2015). Crypto-currency bubbles: an application of the Phillips-Shi-Yu (2013) methodology on Mt. Gox bitcoin prices. Applied Economics, 47(23), 2348-2358. https://doi.org/10.1080/00036846.2015.1005 827

Ciaian, P., Rajcaniova, M., \& Kancs, D. (2016). The economics of BitCoin price formation. Applied Economics, 48(19), 1799-1815. https://doi.org/10.1080/00036846.2015.1109 038

Dwyer, G. P. (2015). The economics of Bitcoin and similar private digital currencies. Journal of Financial Stability, $\quad 17, \quad 81-91$. https://doi.org/10.1016/j.jfs.2014.11.006

Fry, J., \& Cheah, E.-T. (2016). Negative bubbles and shocks in cryptocurrency markets. International Review of Financial Analysis, 47 , 343-352. https://doi.org/10.1016/j.irfa.2016.02.008

Geisler, N. L. (2015). Etika Kristen. Literatur Saat. Hendricks, O. M. (2006). The Politics of Jesus: Rediscovering the True Revolutionary Nature of Jesus' Teachings and How They Have Been Corrupted. Three Leaves Press.

Keraf, A. S. (1995). Etika Bisnis. Kanisius.

Kim, T. (2017). On the transaction cost of Bitcoin.

Finance Research Letters, 23, 300-305. https://doi.org/10.1016/j.frl.2017.07.014

Kusnandar, C. (2017). Sepuluh Perintah Tuhan Bagian Kedua: Kasih Terhadap Manusia Dalam Tinjauan Etika Kristen. Jurnal Ilmiah METHONOMI, 3(2), 73-82. https://methonomi.net/index.php/jimetho/arti cle/view/56

Lawrence, P. (2016). Atlas dan Sejarah Alkitab. BPK Gunung Mulia.

Liu, Y., \& Tsyvinski, A. (2021). Risks and Returns of Cryptocurrency. The Review of Financial
Studies,

34(6),

2689-2727.

https://doi.org/10.1093/rfs/hhaa113

Mastra, A. G. (2019). Teologi Kewirausahaan. Yayasan Taman Pustaka Kristen Indonesia.

Meima, M., \& Pratama, Y. N. (2018). Penggunaan Mata Uang Virtual (Bitcoin) dalam Transaksi Pasar Modal Berdasarkan UU No.7 Tahun 2011 tentang Mata Uang Dihubungkan dengan UU.8 Tahun 1995 tentang Pasar Modal. Wacana Paramarta: Jurnal Ilmu Hukum, 17(2), 83-94. https://doi.org/10.32816/paramarta.v17i2.59

Misra, S., Kashyap, V., Poonacha, K. B., Mukund, A., \& Parameshwar, H. S. (2020). CryptoCurrency: A Black and White Analysis. International Journal of Information Systems and Social Change, 11(2), 24-40. https://doi.org/10.4018/IJISSC.2020040103

Nurjannah, S., \& Artha, I. G. (2019). Bitcoin Sebagai Aset Kripto Di Indonesia Dalam Persepektif Perdagangan. Kherta Negara, 7(9), $1-15$. https://ojs.unud.ac.id/index.php/Kerthanegara /article/view/54494

Pieters, G., \& Vivanco, S. (2017). Financial regulations and price inconsistencies across Bitcoin markets. Information Economics and Policy, $\quad 39, \quad 1-14$. https://doi.org/10.1016/j.infoecopol.2017.02. 002

Puspasari, S. (2020). Perlindungan Hukum bagi Investor pada Transaksi Aset Kripto dalam Bursa Berjangka Komoditi. Jurist-Diction, $3(1)$, 303. https://doi.org/10.20473/jd.v3i1.17638

Razzaq, R. G. (2018). Legalitas Mata Uang Virtual Dalam Perspektif Hukum Indonesia. Lontar Merah, 1(2), 108-122. https://jom.untidar.ac.id/index.php/lontarmer ah/article/view/346

Ronda, D. (2011). Leadership Wisdom. Kalam Hidup.

Setiawan, D. (2021). SOCIAL 


\section{ENTREPRENEURSHIP:}

Penerapan

Kewirausahaan Paulus Bagi Wirausahawan

Kristen Masa Kini. VISIO DEI: JURNAL TEOLOGI KRISTEN. https://doi.org/10.35909/visiodei.v3i1.176

Tampubolon, G. D., Chilyon, P. M., Candra, C. A., \& Zefri. (2010). Investasi Dalam Ekonomi Alkitabiah. In Biblical Economic.

Tomatala, Y. (2010). Spiritual Entrepreneur. YT Leadership Foundation.

Tomatala, Y. (2012). Marthin Billa: Pemimpin Visioner Transformator Futuristik. YT Leadership Foundation.

Tschorsch, F., \& Scheuermann, B. (2016). Bitcoin and Beyond: A Technical Survey on Decentralized Digital Currencies. IEEE Communications Surveys \& Tutorials, 18(3), 2084-2123. https://doi.org/10.1109/COMST.2016.253571 8
Urquhart, A. (2016). The inefficiency of Bitcoin. Economics Letters. https://doi.org/10.1016/j.econlet.2016.09.019 Vranken, H. (2017). Sustainability of bitcoin and blockchains. Current Opinion in Environmental Sustainability, 28, 1-9. https://doi.org/10.1016/j.cosust.2017.04.011

Wagner, C. P. (2005). Pertumbuhan Gereja dan Peranan Roh Kudus. Gandum Mas.

Ying, W., Jia, S., \& Du, W. (2018). Digital enablement of blockchain: Evidence from HNA group. International Journal of Information Management, 39, 1-4. https://doi.org/10.1016/j.ijinfomgt.2017.10.0 04

Yulianton, H., Santi, R. C. N., Hadiono, K., \& Mulyani, S. (2018). Implementasi Sederhana Blockchain. Sintak, 2. https://unisbank.ac.id/ojs/index.php/sintak/art icle/view/6635 